DOI: $10.1515 /$ pts-2016-0025

\title{
STUDY OF THE SYNCHRONOUS RELUCTANCE MOTOR DESIGN
}

\author{
J. Dirba, L. Lavrinovicha, R. Dobriyan \\ Riga Technical University, \\ 12/1 Azenes Str., Riga, LV-1048, LATVIA \\ e-mail: janis.dirba@rtu.lv
}

\begin{abstract}
The paper focuses on studying the external-rotor synchronous reluctance motor. The analysis is performed to estimate the influence of the number of stator slots and non-magnetic areas in the rotor (i.e., flux barriers) on the electromagnetic torque and torque ripple of the studied motor. It is concluded that the increase in the number of stator slots $Z=6$ to $Z=18$ causes an approximately twofold decrease in the ripple factor, but torque increases by $5 \%$. Electromagnetic torque will be increased approximately by $24 \%$, if non-magnetic flux barriers are created in the rotor of the studied synchronous reluctance motor.
\end{abstract}

Keywords: electromagnetic torque, number of the stator slots, synchronous reluctance motor, torque ripple.

\section{INTRODUCTION}

The brushless synchronous motors (permanent-magnet synchronous motors and synchronous reluctance motors) are considered a good alternative to brushed motors, because they have a significantly high level of safety and other advantages [1]-[4].

Permanent-magnet synchronous motors have such disadvantages as high cost of permanent magnets and high electromagnetic torque ripple. High electromagnetic torque ripple of such motors is the result of the cogging torque that is due to the interaction between permanent magnets of the rotor and the stator slots. Synchronous reluctance motors in comparison with permanent-magnet synchronous motors have low value of the electromagnetic power (torque) per unit volume. Moreover, synchronous reluctance motors have high electromagnetic torque ripple that is the result of the rotor magnetic asymmetry.

Synchronous reluctance motors (SynRMs) have neither winding of excitation nor permanent magnets, which is why they are safer and cheaper in comparison with other types of electric motor. SynRM operation principle is based on a deep variation in the magnetic flux due to different reluctance on its way. 
Opportunities of SynRM strongly depend on the structural features of the rotor. The stator of such a motor can be the same as the stator of induction motor, while the rotor is safer and its design is simpler [5]. To increase the value of electromagnetic torque per unit volume of SynRM, the segmental rotor design is proposed. This rotor has ferromagnetic segments separated to each other by non-magnetic gap [6]. However, the influence of the stator slot number and other structural parameters on the motor performance has not been studied in detail.

Questions of the electromagnetic torque ripple reduction are discussed in many papers from different points of view [1]-[3]. Two most common techniques for electromagnetic torque ripple reduction are shortening of stator winding pitch and stator slot skewing [1]. However, slot skewing in synchronous reluctance motors is not an effective technique because, firstly, it does not fully prevent torque ripple and, secondly, it significantly reduces motor torque [2]. Furthermore, in such a case, copper losses will be greater, and winding automatic creation will be quite complicated due longer stator winding.

The main goal of the paper is to study the influence of stator slot number and non-magnetic flux barriers on the electromagnetic torque ripple of SynRM.

\section{PROTOTYPE OF SYNCHRONOUS RELUCTANCE MOTOR}

A two-pole three-phase synchronous reluctance motor having external segmental rotor is selected as an object of the research [6]. Figure 1 presents a crosssection of the motor under investigation, which has a six-slot stator. There are different cases provided for studding, when a number of stator slots: $Z=6, Z=12, Z=18$ and $Z=24$. Outer diameter of the motor is assumed to be a constant value. The rotor of the motor is made of special segmental cores that are composed of electrical steel sheets. In order to decrease the influence of the quadrature magnetic field on the motor operation, segmental rotor is made with additional non-magnetic areas (i.e., flux barriers) in the middle of each segment along the quadrature axis. Holes in the rotor segmental cores (Fig.1) are made for rotor placement in the motor body by stud-bolts.

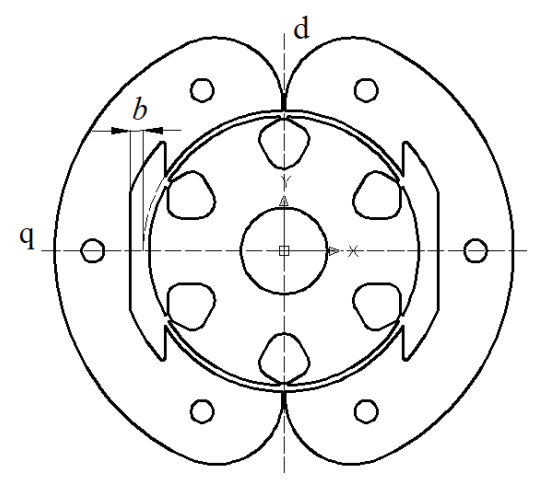

Fig. 1. A cross-section of the prototype.

Width of the additional non-magnetic flux barriers (width $b$ in Fig. 1) is assumed to be a variable value to study its influence on the electromagnetic torque. 


\section{STUDIED MOTOR MAGNETIC FIELD SIMULATION AND RESULT ANALYSIS}

In order to evaluate possibilities of reducing electromagnetic torque ripple of the studied motor and at the same time ensuring the high value of torque, the magnetic field of studied SynRM is simulated by the finite element method. In this case, electromagnetic torque of the studied motor is calculated using the Maxwell stress tensor [7]. In this case, the electromagnetic torque is described with surface integral (1) over a closed surface $\mathrm{S}$ in the middle of the motor air gap.

$$
\mathrm{T}_{\varepsilon \mu}=\oint_{\Sigma}\left(\bar{\rho} \cdot\left[\frac{1}{2 \mu_{0}}\left(\mathrm{~B}_{v}^{2}-\mathrm{B}_{\tau}^{2}\right) \cdot \bar{v}-\frac{1}{\mu_{0}} \mathrm{~B}_{v} \mathrm{~B}_{\tau} \bar{\tau}\right]\right) \delta \Sigma,
$$

where $T_{e m}$ is the electromagnetic torque;

$\mu_{0}$ is vacuum magnetic permeability;

$\bar{n}$ is the normal vector of the point on a closed surface $S$;

$\bar{r}$ is the radius-vector of the point on a closed surface $S$;

$\bar{t} \quad$ is the tangent vector of the point on a closed surface $S$;

$B_{n}$ is the normal component of the magnetic flux density;

$B_{t}$ is the tangential component of the magnetic flux density.

Electromagnetic torque ripple of brushless synchronous motor strongly depends on the number of stator slots and their opening width [8]. Therefore, firstly, the influence of the number of stator slots on the torque ripple is studied in the present research.

Figure 2 shows electromagnetic torque curves depending on the rotation angle of the rotor obtained by magnetostatic simulation of studied SynRM in the cases when $Z=6, Z=12, Z=18$ and $Z=24$.

a) $Z=6$

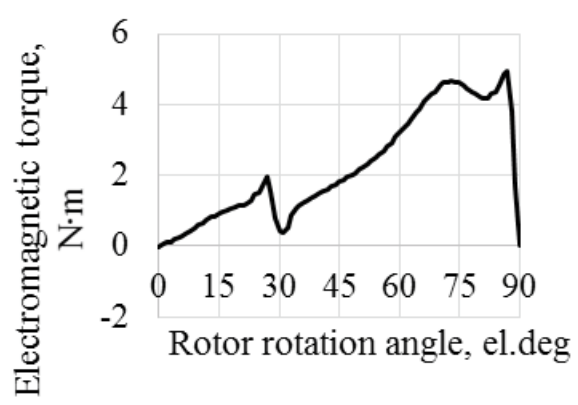

b) $Z=12$

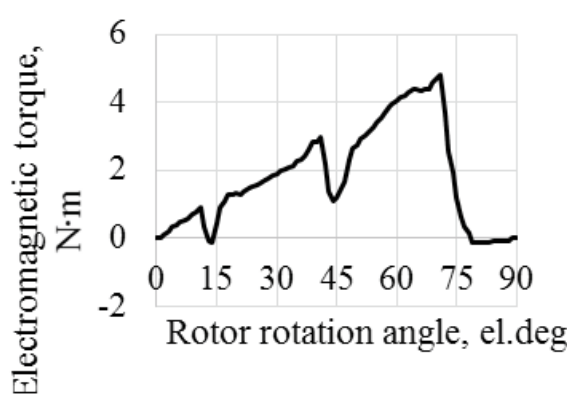


c) $Z=18$

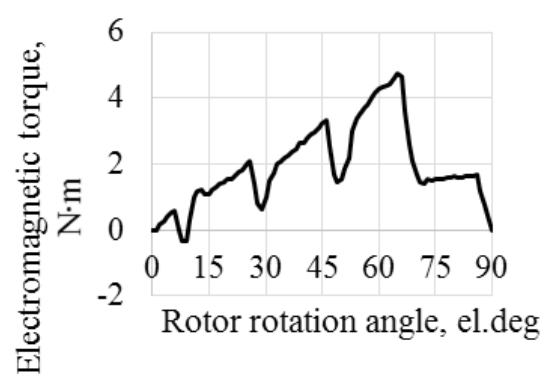

d) $Z=24$

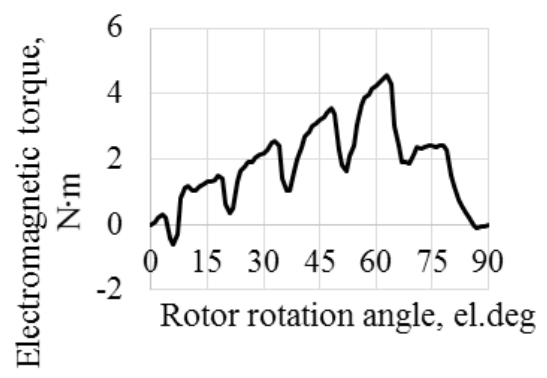

Fig. 2. Electromagnetic torque curves depending on the rotation angle of the rotor at different number of stator slots.

As it is known [9] from (2), electromagnetic torque of synchronous motor with unsaturated magnetic circuit depending on the angle $\varepsilon$ between the rotor direct axis and axis of armature magnetizing force has sinusoidal change.

$$
T_{e m}=\frac{1}{2} m p L_{a d} I_{1}^{2}\left(1-\frac{k_{q}}{k_{d}}\right) \sin (2 \varepsilon),
$$

where $m$ is the number of phases;

$p$ is the number of pole pairs;

$L_{a d}$ is the inductance corresponding to the armature magnetic flux along the direct axis;

$I_{1}$ is the armature current;

$k_{q}$ is the armature reaction factor along the quadrature axis;

$k_{d}$ is the armature reaction factor along the direct axis.

Therefore, it is useful to excrete the fundamental harmonic $T_{e m 1}$ from curves presented in Fig. 2. Thus, torque ripple can be evaluated by the proposed coefficient $k_{p}$, which can be termed as a ripple factor:

$$
\kappa_{\pi}=\frac{\sum_{l=1}^{v}|\Delta \alpha|}{v \cdot \mathrm{T}_{\mu \alpha \xi 1}},
$$

where $n$ is the number of evenly selected points on the half interval of the electromagnetic torque sinusoidal curve;

$\Delta a$ is the difference between values of the electromagnetic torque $T_{e m}$ and the fundamental harmonic of electromagnetic torque $T_{e m 1}$ in relevant points;

$T_{\max 1}$ is the maximum of electromagnetic torque fundamental harmonic.

Relationships $k_{p}=f(n)$ for a different number of stator slots are shown in Fig. 3. From these curves it can be concluded that the selected number of points $n \geq 45$ guarantees sufficiently safe notification of ripple factor $k_{p}$. 


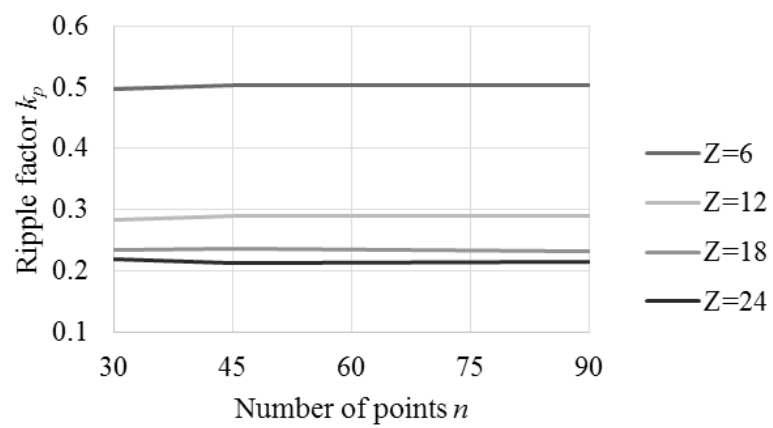

Fig. 3. Relationships $k_{p}=f(n)$ for different cases with the studied number of stator slots.

Figure 4 demonstrates variation of torque $T_{\max 1}$ and ripple factor $k_{p}$ depending on the number of stator slots. Those values are defined from results of prototype magnetic field calculations by (1) and (3).

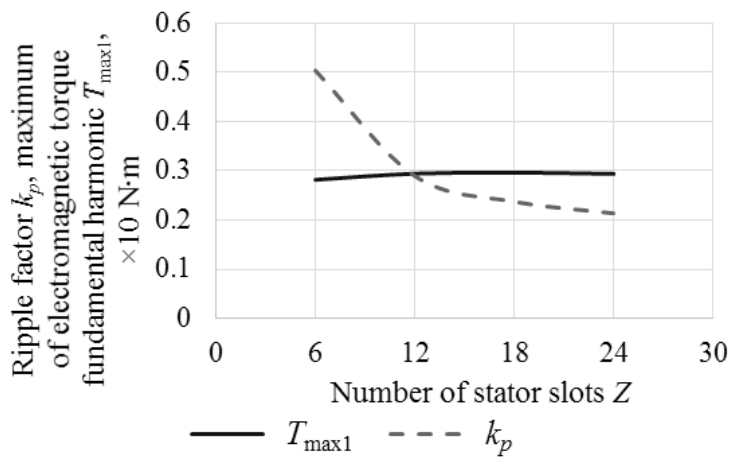

Fig. 4. Variation of torque $T_{\max 1}$ and ripple factor $k_{p}$ depending on the number of stator slots.

Curves in Fig. 4 show that if the number of stator slots increases, ripple factor $k_{p}$ significantly reduces; however, the change of maximum value of the torque fundamental harmonic $T_{\max 1}$ is minor. Thus, the number of stator slots $Z=18$ is the most acceptable variant because, taking into account mechanical strength of stator teeth and stator winding creation, too large number of stator slots is not desirable.

In order to clarify results of additional non-magnetic flux barrier influence on the $T_{\max 1}$ and $k_{p}$ values, some calculations are made by changing width $b$. Figure 5 presents relationships $T_{\max 1}=f(b)$ and $k_{p}=f(b)$ for the studied motor having $Z=18$.

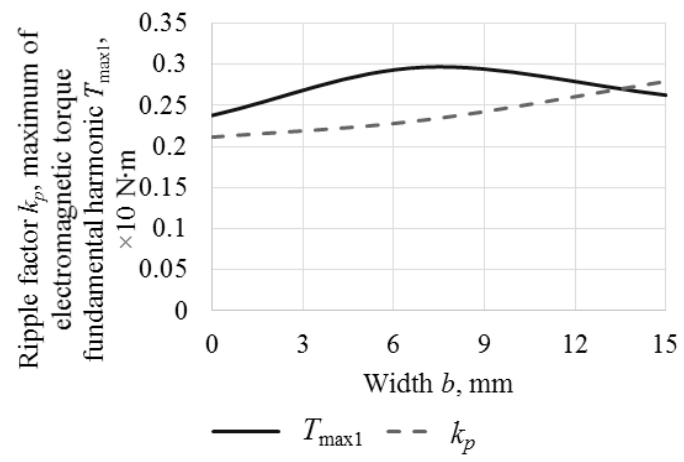

Fig. 5. Torque $T_{\max 1}$ and ripple factor $k_{p}$ versus width of the non-magnetic flux barrier. 
From curves in Fig. 5 it can be concluded that the increase of width $b$ in the beginning causes the increase of torque $T_{\max 1}$ due to the increase of magnetic asymmetry of the rotor; then torque $T_{\max 1}$ reduces due to a significant increase of magnetic circuit saturation. However, the influence of flux barrier width $b$ on the ripple factor $k_{p}$ is not significant.

\section{RESULTS OF EXPERIMENTAL TESTING OF THE STUDIED MOTOR AT BRAKE ROTOR}

Angular curves of a synchronous motor can be determined experimentally in the static mode by powering the armature winding with a certain value of DC current. In this case, the rotor is breaking by constant magnetizing force [9].

According to the method for determination of static electromagnetic torque, the fundamental harmonic of magnetizing force generated by DC current at a brake rotor is to be equal to that generated by $\mathrm{AC}$ current in the case of rotation rotor.

In order to perform experimental testing, the external-rotor motor is mounted on a fixed static shaft. Structural scheme of experimental stand for determination of angular curves for external-rotor motors is shown in Fig. 6.

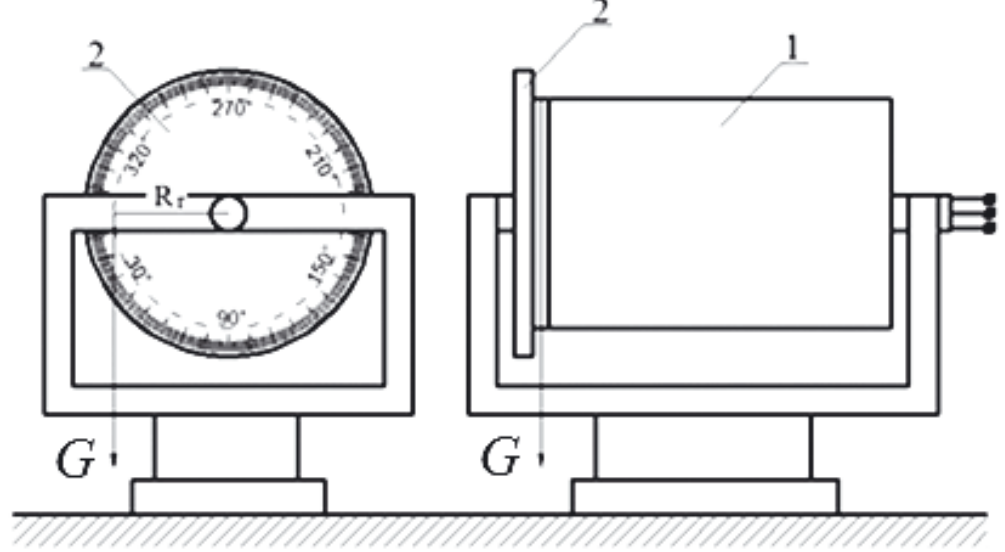

Fig. 6. Structural scheme of experimental testing stand for external-rotor motor: 1 - studied motor; 2 - graduated disc for determination of rotor rotation angle; $G$ - suspended weight to the rotor.

Experimental testing results are compared with results obtained by magnetostatic field simulation of the studied motor. Magnetostatic field simulation is made with two-dimensional software QuickField [10]. Figure 7 presents experimentally obtained angular curves of the studied prototype with $Z=6$ in comparison with calculated curves obtained by magnetostatic field simulation. Evaluated results show a satisfactory coincidence of experimental and numerically calculated results. 


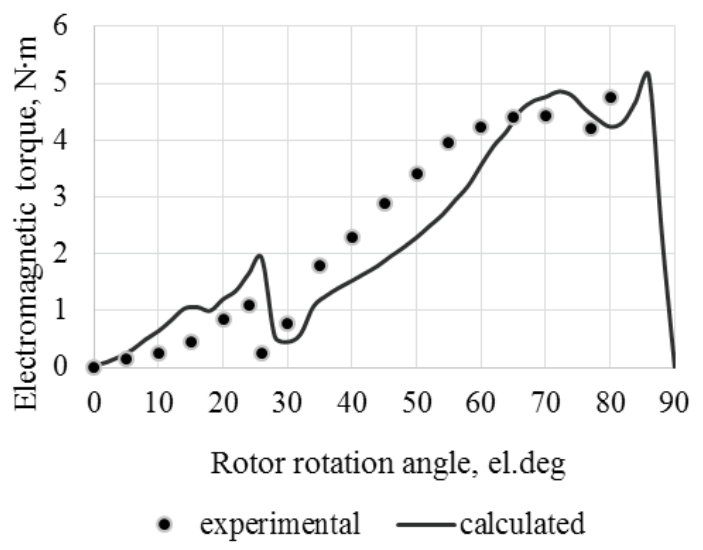

Fig. 7. Experimentally obtained and numerically calculated angular curves of the studied prototype.

\section{CONCLUSIONS}

Based on the results obtained, the following conclusions can be drawn:

1. Ripple factor, which is calculated as the average amount of deviation from the fundamental harmonic of electromagnetic torque curve, can be used for ripple evaluation for synchronous motor.

2. Ripple factor is substantially reduced by increasing the number of stator slots; however, the increase of the torque fundamental harmonic maximum is not significant. Therefore, the increase of the number of stator slots $Z=6$ to $Z=18$ causes an approximately twofold decrease of the ripple factor, but torque increases by $5 \%$.

3. Electromagnetic torque will be increased approximately by $24 \%$, if nonmagnetic flux barriers are created in the rotor of the studied synchronous reluctance motor.

\section{ACKNOWLEDGEMENTS}

The present research has been supported by the State Research Programme "LATENERGI".

\section{REFERENCES}

1. Wang, K., Zhu, Z.Q., Ombach, G., Koch, M., Zhang, S., and Xu, J. (2015). Torque ripple reduction of synchronous reluctance machines: Using asymmetric flux-barrier. International Journal of Computations and Mathematics in Electrical and Electronic Engineering 34 (1): 18-31 DOI: 10.1108/COMPEL-11-2013-0367.

2. Fratta, A., Troglia, G.P., Vagati, A., and Villata, F. (1993). Evaluation of torque ripple in high performance synchronous reluctance machines. In Conf. Rec. IEEE IAS Annu. Meeting (pp. 163-170). Ontario, Canada. 
3. Vagati, A., Pastorelli, M., Franceschini, G., and Petrache, S.C. (1998). Design of lowtorque-ripple synchronous reluctance motors. IEEE Transactions on Industry Applications 34 (4).

4. Dirba, J., Lavrinovicha, L., and Dobriyan, R. (2015). The prospects of synchronous reluctance motors usage in low power electrical devices. Latvian Journal of Physics and Technical Sciences 52 (2), 40-48. ISSN 0868-8257.

5. Lipo, T.A. (1991). Synchronous reluctance machines - A viable alternative for AC drives. Electric Machines and Power Systems, 659-671.

6. Pugachevs, V., Dirba, J., Kukjane, L., Levins, N., and Orlova, S. (2012). Patent of the Republic of Latvia. LV 14418 B. (in Latvian).

7. Bianchi, N. (2005). Electrical machine analysis using finite elements. CRC Press, Boca Raton, FL, Taylor \& Francis.

8. Nizam, M., Waloyo, H.T., Inayati. (2013). Design of optimal outer rotor brushless DC motor for minimum cogging torque. In Joint International Conference on Rural Information \& Communication Technology and Electric-Vehicle Technology (pp. 1-4).

9. Lavrinovicha, L. (2014). Design and optimisation of brushless synchronous motors for use in low power equipment. Summary of PhD Thesis. Riga: RTU.

10. Tera Analysis (2010). QuickField. Finite Element Analysis System. Version 5.7. User's Guide (Denmark).

\title{
SINHRONĀ REAKTĪVĀ DZINĒJA KONSTRUKCIJAS PĒTĪJUMI
}

\author{
J. Dirba, L. Lavrinoviča, R. Dobrijans
}

Kopsavilkums

Aplūkots sinhronais reaktīvais dzinējs ar ārējo rotoru. Analizēta dzinēja statora rievu skaita un rotora nemagnētisko barjeru ietekme uz elektromagnētisko momentu un tā pulsācijām. Parādīts, ka, palielinot rievu skaitu no $Z=6$ uz $Z=18$, pulsācijas koeficients samazinās aptuveni divas reizes, bet moments pieaug par $5 \%$. Izveidojot pētāmā sinhronā reaktîvā dzinēja ārējā rotorā papildu nemagnētiskas barjeras, momentu var palielināt par 24\%.

10.01.2016. 